\title{
INTRAPERITONEAL BLOOD TRANSFUSION IN CHILDREN IN ACCRA WITH SPECIAL REFERENCE TO THE TREATMENT OF KWASHIORKOR
}

\author{
BY \\ SUSAN B. G. OFORI ATTA \\ From the Princess Marie Louise Hospital, Accra, Ghana
}

(RECEIVED FOR PUBLICATION NOVEMBER 11, 1957)

The giving of blood to small children presents particular difficulties to medical practitioners in West Africa. Equipment is often inadequate and the time required to ensure the success of the transfusion can often be ill-spared from numerous other hospital and out-patient duties. In addition, the children are usually ill-nourished and dehydrated and intravenous therapy is a major undertaking to those unpractised in paediatric techniques. Waite, Colucci and Glaser (1956) recorded the successful transfusion of blood by the intraperitoneal route in young children and this appears to be a simple and rapid procedure which, if successful, would be of the greatest benefit to practitioners and their young patients in West Africa. This method has been used in Accra and, to date, 43 intraperitoneal blood transfusions have been given to 36 children with clinically satisfactory results. In this paper the methods utilized are outlined and the results briefly discussed. Details of 15 transfusions which have been given to 11 malnourished babies are given.

\section{Methods}

The majority of the children were suffering from marasmus, marasmic kwashiorkor or kwashiorkor. Intercurrent infection and multiple infestations were common. The patients with florid signs of kwashiorkor with oedema were treated with skimmed milk alone or skimmed milk with soya bean flour and/or fish until the oedema disappeared (the child then looking the picture of marasmic kwashiorkor) before transfusion was given.

The usual routine in saline and albumin grouping and compatibility tests was followed and the results confirmed by an indirect Coombs test. All the children were rhesus positive (anti-D). In Accra the incidence of the sickle-cell and haemoglobin C traits is in the region of $19 \%$ and $10 \%$ respectively and the blood with these traits is normally stored and utilized by the transfusion service (Edington, 1956). It was not, however, employed for intraperitoneal transfusions excluding one instance in which $\mathrm{S}$ trait blood was given intraperitoneally to one sickling negative baby and the subsequent appearance of the sickling positive cells in the peripheral circulation was studied.

The patients were prepared as for paracentesis abdominis. (In Ghana special care has to be taken in the examination of the liver, spleen and bladder.) The patient was propped up and the abdominal wall and peritoneum 2 inches below and lateral to the umbilicus was anaesthetized with $1 \%$ novocaine. The usual routine giving set with a 20 -gauge needle was employed and the blood allowed to drip through the set before the needle was inserted into the peritoneal cavity. The amount usually given was $20 \mathrm{ml}$. per lb. body weight and the rate of flow was regulated to 30 drops per minute. A cover of penicillin was given during the transfusion and sedation when required. Following transfusion a course of antimalarial therapy was prescribed to obviate the possibility of transmitting malaria.

\section{Results}

Three of the 39 children transfused died. The minimum period between transfusion and death was two days and the maximum 20 weeks. In no instance was the transfusion thought to be implicated in the cause of death. Necropsies were performed on all three children. A child suffering from severe marasmus died two days after transfusion. Necropsy revealed the cause of death to be marasmus and bronchopneumonia. The free blood in the peritoneal cavity was fluid and uninfected and no adhesions were noted. Haemolysis had not occurred. A second child, an orphan, aged 4 months and weighing only $4 \mathrm{lb} .10 \mathrm{oz}$, had been fed entirely on maize gruel from the age of 2 days. Death 
occurred 12 weeks after the transfusion and a necropsy established that the cause was hydronephrosis, pyelonephritis, interstitial pneumonitis and malnutrition. The peritoneal cavity contained a few black specks in the paracolic gutter but was otherwise normal. A third child died 20 weeks after transfusion. The peritoneal cavity was free from infection and adhesions.

From the results of these necropsies it would appear that the introduction of compatible blood into the peritoneal cavity is unlikely to lead to complications in later life.

The infants in general withstood the procedure well: only one severe reaction occurred and that was in the sickling negative infant who received sickling positive blood. The complications observed after transfusion were abdominal distension in 27 cases (this was usually mild, gave no cause for anxiety and cleared up within 48 hours), mild pyrexia in 26 cases, and one abdominal haematoma which resolved spontaneously. There were no cases with melaena, bowel symptoms or jaundice.

The sickle-cell negative patient who received compatible sickling positive blood $(20 \mathrm{ml}$. per $\mathrm{lb}$. body weight) showed the most severe reaction-the temperature rose to $102 \cdot 8^{\circ} \mathrm{F}$. and vomiting, restlessness and abdominal distension occurred. These symptoms regressed spontaneously at the end of four days. The eventual response to transfusion in this patient was considered, however, to be eminently satisfactory. The rate of appearance of the sickling positive cells in the peripheral blood of the patient was studied and the results are shown in Table 1.

TABLE 1

PERCENTAGE OF SICKLING POSITIVE CELLS (S) APPEARING IN PERIPHERAL BLOOD OF NON-SICKLING INFANT

\begin{tabular}{c|c|c|c|c|c}
\hline Day* & S Cells & Day* & S Cells & Day* & S Cells \\
\cline { 1 - 2 } & $\%$ & & $\%$ & & $\%$ \\
\cline { 1 - 2 } 1 & Scanty & 49 & 9 & 70 & $0 \cdot 2$ \\
2 & Scanty & 53 & 8 & 71 & $0 \cdot 1$ \\
4 & 1 & 56 & 8 & 73 & $0 \cdot 5$ \\
9 & 4 & 58 & 7 & 73 & Scanty \\
21 & 15 & 60 & 5 & 74 & Nil \\
28 & 12 & 69 & 1 & 75 & Nil \\
\hline
\end{tabular}

* Day following transfusion.

From Table 1 it appears that, following intraperitoneal blood transfusion, the transfused cells reach their greatest concentration in the peripheral blood two to four weeks after transfusion. No sickling positive cells were detected in the peripheral blood at the end of 74 days. No explanation can be given for this. The recipient did not appear to be suffering from a haemolytic anaemia and, as the average life of the erythrocyte is $\mathbf{1 2 0}$ days and as sickle-cell trait cells are known to survive normally, it was expected that the sickled cells would be detected for a longer period.

The clinical response of the patients to blood

TABLE 2

CLINICAL DETAILS OF 11 BABIES SUFFERING FROM SEVERE MALNUTRITION TREATED BY INTRAPERITONEAL BLOOD TRANSFUSIONS

\begin{tabular}{|c|c|c|c|c|c|c|c|c|}
\hline $\begin{array}{l}\text { Case } \\
\text { No. }\end{array}$ & $\begin{array}{c}\text { Age } \\
\text { (months) }\end{array}$ & $\begin{array}{l}\text { Weight } \\
\text { Tra } \\
\text { (lb.) }\end{array}$ & $\begin{array}{l}y \text { of } \\
\text { on } \\
\text { oz.) }\end{array}$ & Condition & $\begin{array}{l}\text { Hb. before } \\
\text { Transfusion } \\
(\%)\end{array}$ & $\underset{\substack{\text { Hb. after } \\
\text { Transfusion }}}{\text { (\%) }}$ & Result & Remarks \\
\hline 1 & 8 & 9 & 4 & $\begin{array}{l}\text { (Failure to thrive) } \\
\text { Marasmus }\end{array}$ & 60 & 85 & Discharged & \\
\hline 2 & $4 \frac{1}{2}$ & 5 & 4 & Marasmus & 57 & 70 & $\begin{array}{l}\text { Died after } \\
12 \text { weeks }\end{array}$ & \\
\hline 3 & 14 & 11 & 3 & Marasmic kwashiorkor & $\begin{array}{l}40^{*} \\
65\end{array}$ & $\begin{array}{l}60 \\
78\end{array}$ & Discharged & Slow progress \\
\hline 4 & 12 & 11 & 0 & Marasmic kwashiorkor & 55 & 83 & Discharged & \\
\hline 5 & 5 & 7 & 2 & $\begin{array}{l}\text { (Failure to thrive) } \\
\text { Marasmus }\end{array}$ & $\begin{array}{l}45 \\
60\end{array}$ & $\begin{array}{l}67 \\
90\end{array}$ & Discharged & $\begin{array}{l}\text { Attack of malaria before } 2 \text { nd } \\
\text { transfusion }\end{array}$ \\
\hline 6 & 9 & 8 & 1 & Marasmus & 53 & 75 & Discharged & \\
\hline 7 & $44 \frac{1}{2}$ & 22 & 11 & Marasmic kwashiorkor & 55 & 79 & Discharged & \\
\hline 8 & 12 & 10 & $2 \frac{1}{2}$ & Kwashiorkor & 44 & 67 & Discharged & \\
\hline 9 & $30 \mathrm{~T}$ & 11 & 1 & Kwashiorkor & 55 & 71 & Discharged & \\
\hline 10 & 18 & 13 & $\mathbf{0}$ & Marasmic kwashiorkor & $\begin{array}{l}50 \\
63\end{array}$ & $\begin{array}{l}70 \\
81\end{array}$ & $\begin{array}{l}\text { Died } 20 \\
\text { weeks after } \\
\text { transfusion }\end{array}$ & $\begin{array}{l}\text { Two attacks of malaria before } \\
\text { 2nd transfusion }\end{array}$ \\
\hline 11 & about 10 & 9 & 1 & Kwashiorkor & $\begin{array}{l}45 \\
69\end{array}$ & $\begin{array}{l}68 \\
80\end{array}$ & Discharged & Slow progress \\
\hline
\end{tabular}

- Where two figures appear under haemoglobin before and after transfusion, the top figure refers to the first transfusion and the lower figure to the second transfusion. 
transfusion was good. Brief details of 11 severely malnourished patients who had received 15 transfusions are given in Table 2.

It is difficult to assess the results of treatment in kwashiorkor, and controlled studies were not possible. Clinically, however, the babies appeared to benefit immensely from the transfusion (Figs. 1

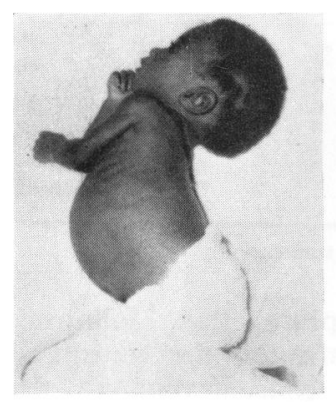

(a)

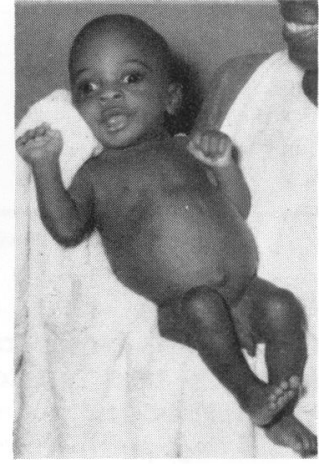

(b)

FIG. 1.-Case 5. Boy aged 5 months, (a) before treatment: marasmus; weight $7 \mathrm{lb} .2 \mathrm{oz}$. and $(b)$ after treatment.

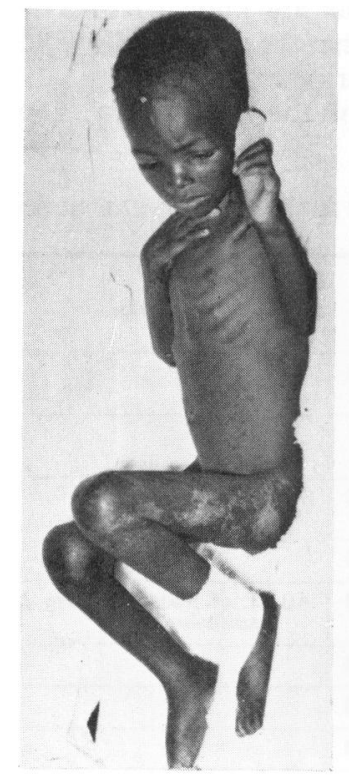

(a)

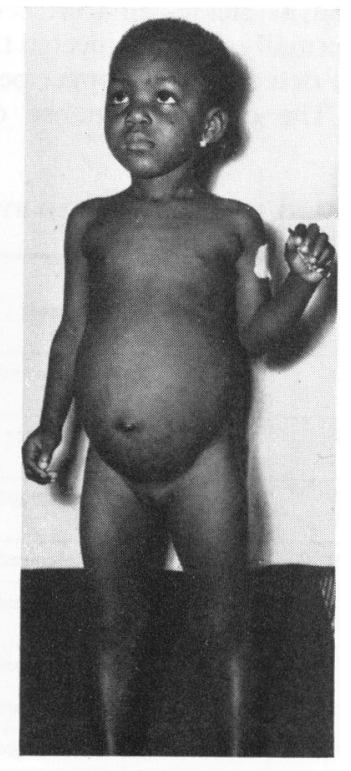

(b)
FIG. 2.-Case 7. Girl aged 44! months, (a) before treatment: marasmic kwashiorkor; weight $22 \mathrm{lb} .11 \mathrm{oz}$. and (b) after treatment. and 2) and, perhaps most important, the nursing staff were most enthusiastic about it as a method of treatment. Not only did the transfusion increase the haemoglobin level of the blood but it appeared to increase the child's resistance to intercurrent infection, the incidence of which, especially of staphylococcal infection, was lower in these children. The rate of recovery was also usually greatly accelerated. Four patients, however, showed a comparatively slow response and in these cases transfusion was repeated in six weeks when a rapid recovery ensued.

\section{Comment}

In the malnutritional syndromes seen in Accra the most important single factor lacking in the diet is protein and it would appear that the giving of blood is a simple and rapid method of remedying this deficiency. Hitherto blood has not been used in the treatment of marasmus and kwashiorkor in Accra in view of the technical difficulties involved, and also because it is only recently that blood has become readily available for transfusion. The intraperitoneal transfusion provides a simple and safe method of giving blood to these patients. Clinically the infants have responded well to this form of therapy. It is regrettable that full biochemical investigations could not be undertaken in each case but time and staff were lacking and it is hoped that in the future a more intensive investigation can be done. Meanwhile, however, it has been shown that intraperitoneal blood transfusion is a useful and simple therapeutic measure in West Africa.

\section{Summary}

Intraperitoneal blood transfusion has been found to be a safe and simple method of treatment. Erythrocytes are absorbed from the peritoneal cavity into the peripheral circulation. Abdominal complications are unlikely to occur in later life.

My thanks are due to the Chief Medical Officer, Ghana, for permission to publish, to Dr. G. M. Edington for advice and details of the necropsies, to the nursing staff of the Princess Marie Louise Hospital and to the staff of the Medical Research Institute, particularly Mr. Sackey.

\section{REFERENCES}

Edington, G. M. (1956). W. Afr. med. J., n.s. 5, 71. Waite, M. E., Colucci, D. D. and Glaser, J. (1956). Amer. J. Dis. Child., 91, 561 . 